\title{
Survey Of Students Sport Activity During Covid-19 Pandemic
}

\author{
Pratama Dharmika Nugraha'), Made Bang Redy Utama ${ }^{2)}$, Adi ${ }^{3)}$ Ahmad \\ Sulaiman ${ }^{4}$ \\ Program studi Ilmu Keolahragaan \\ Fakultas Ilmu Kesehatan dan Sains \\ ${ }^{1}$ Universitas PGRI Madiun, Jawa Timur Indonesia \\ ${ }^{2}$ Universitas Negeri Semarang, Jawa Tengah Indonesia \\ ${ }^{3}$ Universitas Nahdlatul Ulama Sunan Giri Bojonegoro, Jawa Timur Indonesia \\ ${ }^{4}$ Universitas Muhammadiyah Jember, Jawa Timur Indonesia \\ Email: ${ }^{1}$ pratama.dharmika@ unipma.ac.id, ${ }^{2}$ bangredy1@ gmail.com, ${ }^{3}$ sajaadhie@ gmail.com, \\ ${ }^{4}$ ahmadsulaiman@unmuhjember.ac.id
}

\begin{abstract}
This research aimed to find out sport/work out activities carried out by students during covid-19 pandemic. Sport activity is very necessary to increase endurance, in addition to exercise that is done regularly, the right intensity can improve fitness. The research method used a descriptive research approach by conducting a survey to 427 students from public and private universities. The data collection technique was conducted by using a questionnaire utilized the Google form application. Thus, the questionnaire could be filled out online. The results of the research showed that the most exercise conducted during the co-19 pandemic period was cardio exercise. Cardio exercise is categorized in aerobic activities. Sports activities are mostly carried out at home.
\end{abstract}

Keywords: Students Sport Activity, Covid-19, Pandemic.

\section{Survei Aktivitas Olahraga Mahasiswa Selama Pandemi Covid-19}

\begin{abstract}
ABSTRAK
Tujuan penelitian ini untuk mengetahui aktivitas olahraga yang dilakukan mahasiswa selama masa pandemi covid-19. Kegiatan olahraga sangat dibutuhkan untuk meningkatkan daya tahan tubuh, selain itu olahraga yang dilakukan secara teratur dan intensitas yang tepat dapat meningkatkan kebugaran. Metode penelitian menggunakan pendekatan penelitian deskriptif dengan melakukan survei pada 427 mahasiswa dari PTN dan PTS. Teknik pengambilan data dilakukan dengan menggunakan kuisioner yang memanfaatkan aplikasi google form sehingga angket dapat diisi secara online. Hasil penelitian menunjukan olahraga yang paling banyak dilakukan selama masa pandemi covid-19 adalah olahraga kardio yang termasuk dalam kegiatan yang bersifat aerobik. Kegiatan olahraga lebih banyak dilakukan di rumah.
\end{abstract}

Kata Kunci: Aktivitas Olahraga Mahasiswa, Covid-19, Pandemi.

Info Artikel

Dikirim

Diterima

Dipublikasikan
: 13 Mei 2020

: 30 Juli 2020

: 12 November 2020
(C) 2020 IKIP BUDI UTOMO MALANG

P-ISSN 2613-9421

E-ISSN 2654-8003

\footnotetext{
$\bowtie$ Alamat korespondensi: pratama.dharmika@unipma.ac.id

Universitas PGRI Madiun, Jl. Setiabudi No.85, Kanigoro, Kec. Kartoharjo, Kota Madiun, Jawa Timur 63118, Indonesia
} 


\section{PENDAHULUAN}

Sekelompok kasus pneumonia muncul mulai akhir bulan Desember 2019 di Wuhan Cina yang disebabkan oleh virus yang menyerang sistem pernapasan, yang kemudian dinamai sebagai penyakit virus corona (COVID-19) oleh badan Kesehatan dunia WHO (He et al., 2020). Virus yang tergolong baru ini menyebar dengan cepat. Epidemi covid-19 menyebar dari Cina ke seluruh dunia yang menyebabkan berbagai kegiatan menjadi terhambat seperti kegiatan Pendidikan di sekolah/kampus, olahraga, proses produksi, laju perekonomian, dll. Kondisi tersebut berdampak pada sektor pekerjaan yang harus dikerjakan dari rumah. Sektor pendidikan juga tidak terlepas dari dampak penyebaran virus tersebut, untuk memutus rantai penyebaran covid-19 kegiatan sekolah maupun kuliah harus dilakukan dari rumah. Meskipun belajar dari rumah, sebagai generasi muda tentunya diwajibkan untuk tetap produktif melalui kegiatan belajar yang dilakukan dari rumah. Tanggal 20 Januari 2020 organisasi kesehatan dunia (WHO) menyatakan bahwa wabah virus corona merupakan keadaan darurat yang menjadi perhatian internasional, serta pada tanggal 8 Februari 2020 WHO melaporkan 34.886 kasus yang dikonfirmasi secara global dengan 34.589 di antaranya terjadi di Cina termasuk 6.101 kasus parah dan 723 kematian (Chen et al., 2020).

Aktifitas fisik remaja di Cina mengalami penurunan selama masa pandemic covid-19, aktivitas fisik per minggu dari 540 menit/minggu menjadi 105 menit/minggu, tidak aktif yang awalnya 21,3\% meningkat menjadi $65,6 \%$, aktivitas fisik remaja terpenuhi $18,8 \%$ turun menjadi $16,7 \%$, aktivitas fisik yang dilakukan remaja sebelum pandemic 60,0\% turun menjadi 17,7\% (Xiang, 2020). Kegiatan olahraga perlu dilakukan di rumah secara teratur dan intensitas yang tepat, karena berdasarkan penelitian tentang epidemologis menunjukan bahwa Latihan fisik teratur dapat menurunkan kejadian dan resiko kematian akibat influenza dan pneumonia (Fallon, 2020). Badan Kesehatan dunia WHO menganjurkan aktifitas fisik perlu dilakukan 150 menit/minggu mulai hari intensitas ringan, sedang, hingga berat secara bertahap (Warburton \& Bredin, 2017). Kebugaran fisik yang diperoleh melalui aktifitas fisik teratur terbukti dapat meningkatkan kinerja akademik di sekolah, siswa yang teratur melakukan aktivitas olahraga aerobik selama 30 menit memiliki kemampuan kognitif yang 
lebih baik dari pada siswa yang lebih banyak menghabiskan waktu untuk menonton televisi IOM (Institute of Medicine), 2013).

Kesehatan merupakan sesuatu yang penting dalam kehidupan manusia karena kesehatan diperlukan untuk melaksanakan aktivitas sehari-hari, salah satu cara untuk menjaga maupun meningkatkan kesehatan adalah dengan berolahraga (Prasetyo, 2013). Selama masa pandemi covid-19 setiap orang dihimbau untuk menjaga kesehatan dengan mengkonsumsi makanan bergizi dan olahraga secara teratur. Pemerintah juga menghimbau masyarakat untuk tetap di rumah saja untuk memutus rantai penyebaran virus covid-19. Kondisi yang mewajibkan di rumah saja tentunya juga dapat menimbulkan dampak negatif pada kondisi psikologi karena berbagai faktor. Kebiasaan olahraga secara teratur dapat menurunkan tingkat stress (cortisol hormone) dan meningkatkan feel good hormone (endorphin hormone) (Andalasari \& Berbudi BL, 2018).

Banyak bukti yang menunjukan bahwa olahraga yang dilakuakan secara teratur dalam kehidupan dapat mecegah timbulnya 40 kondisi atau penyakit kronis, karena olaraga dapat menunjang kualitas hidup (Ruegsegger \& Booth, 2018). Berikut merupakan 40 kondisi yang disebabkan oleh kurangnya aktivitas fisik: 1) Accelerated biological aging/premature death, 2) Aerobic (cardiorespiratory) fitness (VO2max), 3) Arterial dyslipidemia, 4) Balance, 5) Bone fracture/falls 6) Breast cancer, 7) Cognitive dysfunction, 8) Colon cancer, 9) Congestive heart failure, 10) Constipation 11) Coronary (ischemic) heart disease 12) Deep vein thrombosis, 13) Depression and anxiety, 14) Diverticulitis, 15) Endometrial cancer 16) Endothelial dysfunction, 17) Erectile dysfunction 18) Gallbladder diseases 19) Gestational diabetes 20) Hemostasis 21) Hypertension 22) Immunity, 23) Insulin resistance, 24) Large arteries lose more compliance with aging, 25) Metabolic syndrome, 26) Nonalcoholic fatty liver disease, 27) Obesity, 28) Osteoarthritis, 29) Osteoporosis, 30) Ovarian cancer, 31) Pain, 32) Peripheral artery disease, 33) Preeclampsia, 34) Polycystic ovary syndrome, 35) Prediabetes, 36) Rheumatoid arthritis 37) Sarcopenia, 38) Stroke, 39) Tendons being less stiff, 40) Type 2 diabetes. Berikut merupakan rekomendasi kegiatan olahraga untuk anak-anak, remaja, dewasa, dan lansia/tua. 
Table. 1 rekomendasi kegiatan olahraga untuk anak-anak, remaja, dewasa, dan lansia/tua (Malm et al., 2019).

\begin{tabular}{|c|c|c|}
\hline Kelompok sasaran & Rekomendasi & Tujuan \\
\hline \begin{tabular}{llr}
\multicolumn{2}{l}{ Anak-anak } & dan \\
remaja usia & $6-17$ \\
tahun. & & \\
\end{tabular} & $\begin{array}{l}\text { 1. Aktivitas olahraga dengan } \\
\text { intensitas sedang selama } \\
60 \text { menit dapat dilakukan } \\
\text { setiap hari. } \\
\text { 2. Latihan penguatan otot } \\
\text { yang disesuaikan dengan } \\
\text { usia pertumbuhan dan } \\
\text { perkembangan dapat } \\
\text { dilakuakn } 3 \text { kali } \\
\text { seminggu. }\end{array}$ & $\begin{array}{l}\text { 1. } \begin{array}{l}\text { Membantu proses } \\
\text { pengembangan otot, sistem } \\
\text { kerangka, dan sistem saraf. }\end{array} \\
\text { 2. Menjaga berat badan ideal. } \\
\text { 3. Meningkatkan kesehatan fisik } \\
\text { dan mental. } \\
\text { 4. } \begin{array}{l}\text { Membantu proses } \\
\text { perkembangan sosial dan } \\
\text { peningkatan rasa percaya diri. }\end{array} \\
\text { 5. Peningkatan kemampuan } \\
\text { belajar. diberikan } \\
\text { 6. Rekomendasi dapat diberis } \\
\text { untuk individu dengan kondisi } \\
\text { normal, tetapi untuk yang } \\
\text { memiliki suatu penyakit } \\
\text { tertentu dapat diberikan } \\
\text { rekomendasi khusus dari ahli } \\
\text { terkait. }\end{array}$ \\
\hline $\begin{array}{l}\text { Orang dewasa usia } \\
\text { 18-64 tahun. }\end{array}$ & $\begin{array}{l}\text { 1. Melakukan aktivitas } \\
\text { olahraga yang bersifat } \\
\text { aerobik } 150 \text { menit per } \\
\text { minggu dengan intensitas } \\
\text { sedang. } \\
\text { 2. Aktivitas olahraga } 75 \\
\text { menit per minggu dengan } \\
\text { intensitas tinggi. } \\
\text { 3. Jadwal latihan perlu diatur } \\
\text { secara teratur. } \\
\text { 4. Latihan penguatan otot } \\
\text { dapat dilakukan } \\
\text { setidaknya dua kali per } \\
\text { minggu. }\end{array}$ & $\begin{array}{l}\text { 1. Peningkatan kinerja aerobik } \\
\text { dan kekuatan otot. } \\
\text { 2. Rekomendasi bersifat } \\
\text { universal, tetapi bagi yang } \\
\text { sakit dapat diberikan } \\
\text { rekomendasi khusus dari ahli } \\
\text { terkait. } \\
\text { 3. Meminimalkan resiko terkena } \\
\text { penyakit seperti gangguan } \\
\text { kardiovaskular, gangguan } \\
\text { pencernaan, kanker, dan patah } \\
\text { tulang. }\end{array}$ \\
\hline Tua usia $>64$ tahun. & $\begin{array}{l}\text { 1. Latihan yang berisifat } \\
\text { meningkatkan } \\
\text { keseimbangan. } \\
\text { 2. Melakukan aktivitas yang } \\
\text { bersifat aerobik dengan } \\
\text { intensitas ringan sampai } \\
\text { sedang. } \\
\text { 3. Melakukan } \\
\text { penguatan otot. }\end{array}$ & $\begin{array}{l}\text { 1. Meningkatan keseimbangan. } \\
\text { 2. Meningkatkan kapasitas kerja } \\
\text { aerobik. } \\
\text { 3. Meningkatkan kekuatan otot. } \\
\text { 4. Meningkatkan kemandirian } \\
\text { dalam kehidupan sehari-hari. } \\
\text { 5. Rekomendasi bersifat } \\
\text { universal, tetapi bagi yang } \\
\text { sakit dapat diberikan } \\
\text { rekomendasi khusus dari ahli } \\
\text { terkait. }\end{array}$ \\
\hline
\end{tabular}




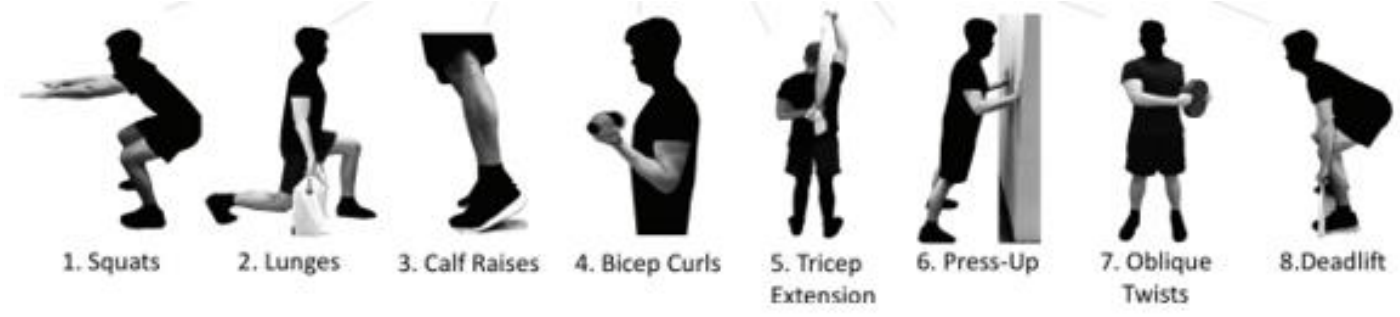

Gambar 1. Gerakan Latihan Kekuatan dan Fleksibilitas

Sumber. (Cegielski et al., 2017)

Kegiatan aktivitas kebugaran jasmani yang dilakukan terdiri dari: 1) squats, 2) lunges, 3) calf raises, 4) bicep curls, 5) tricep extension, 6) press-up, 7) oblique twists, dan 8) deadlift, gerakan-gerakan tersebut dilakukan 12 repetisi x 3 set selama 4 minggu (Cegielski et al., 2017). Gerakan-gerakan yang menggunakan alat dapat dilakukan sesuai dengan peralatan yang ada di rumah, serta tingkatan bebannya pun dapat disesuaikan dengan kemampuan masing-masing siswa. Zona latihan yang direkomendasikan untuk pemula yaitu 60\%-70\% dari repetisi maksimal (1 RM) (Garber et al., 2011).

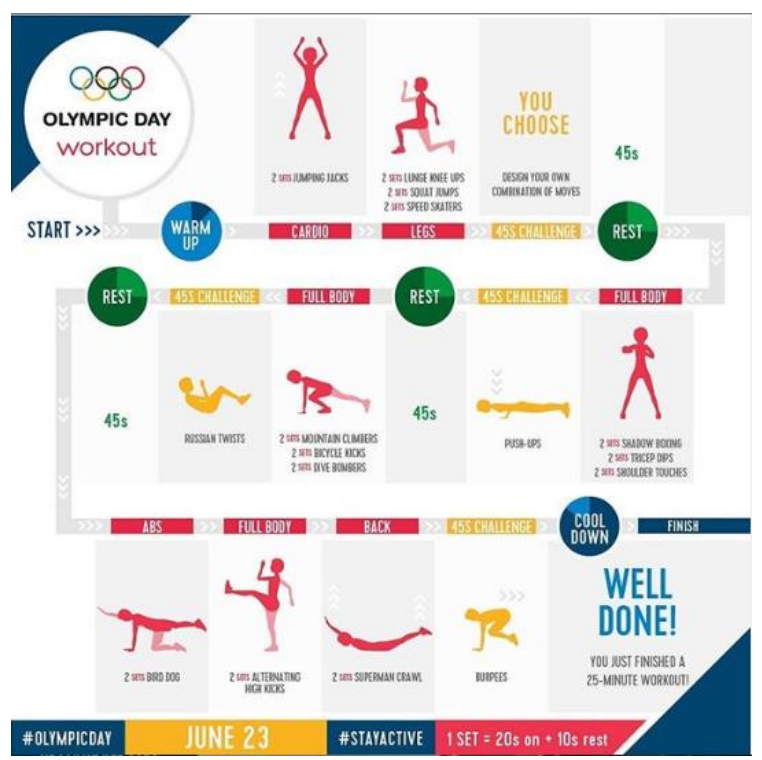

Gambar 2. Full Body Workout Exercise

Sumber. (Olympic, 2020)

Berdasarkan hasil penelitian tersebut dapat diartikan bahwa aktivitas fisik maupun olahraga dapat membantu meningkatkan sistem kekebalan tubuh serta dapat meningkatkan kualitas kesehatan dan kebugaran. Berdasarkan permasalahan tersebut, perlu dilakukan survei terkait kegitan belajar dan aktivitas olahraga selama masa pandemi covid-19. Data tersebut tentunya akan bermanfaat untuk 
mengetahui kondisi mahasiswa selama dilakukan kegiatan pembelajaran dari rumah. Selain itu data juga dapat bermanfaat bagi penelitian-penelitan yang akan dilakukan selanjutnya terkait aktivitas olahraga selama masa pandemi covid-19.

\section{METODE}

Penelitian ini dilakukan dengan pendekatan derkriptif yang diarahkan untuk menyajikan gejala, fakta, maupun kejadian secara sistematis dan akurat tentang sampel yang diteliti (Riyanto, 2010). Hubungan dari sumber data, metode dan instrumen dijadikan pedoman dalam melakukan pengumpulan data (Arikunto, 2010). Sumber data penelitian ini berasal dari hasil survei yang dilakukan pada 427 orang mahasiswa dari beberapa PTN dan PTS di Indonesia. Penyebaran angket dilakukan melalui google form, yang dilakukan pada bulan April sebelum bulan puasa. Teknik pengumpulan data menggunakan kuisioner yang telah direkomendasikan oleh profesor di bidang keolahragaan, kuisioner tersebut berisi pertanyaan tentang kegiatan belajar dan olahraga yang dilakukan mahasiswa selama masa pandemi covid-19. Angket tersebut telah melalui tahap validasi ahli Teknik analisis data dilakukan dengan cara melakukan tabulasi menggunakan excel kemudian melakukan penyajian yang telah disusun sehingga mudah untuk dipahami. Setelah itu dilakukan verifikasi data panelitian untuk membuat kesimpulan berdasarkan kondisi yang ada serta literasi yang relevan (Sugiyono, 2010).

\section{HASIL DAN PEMBAHASAN}

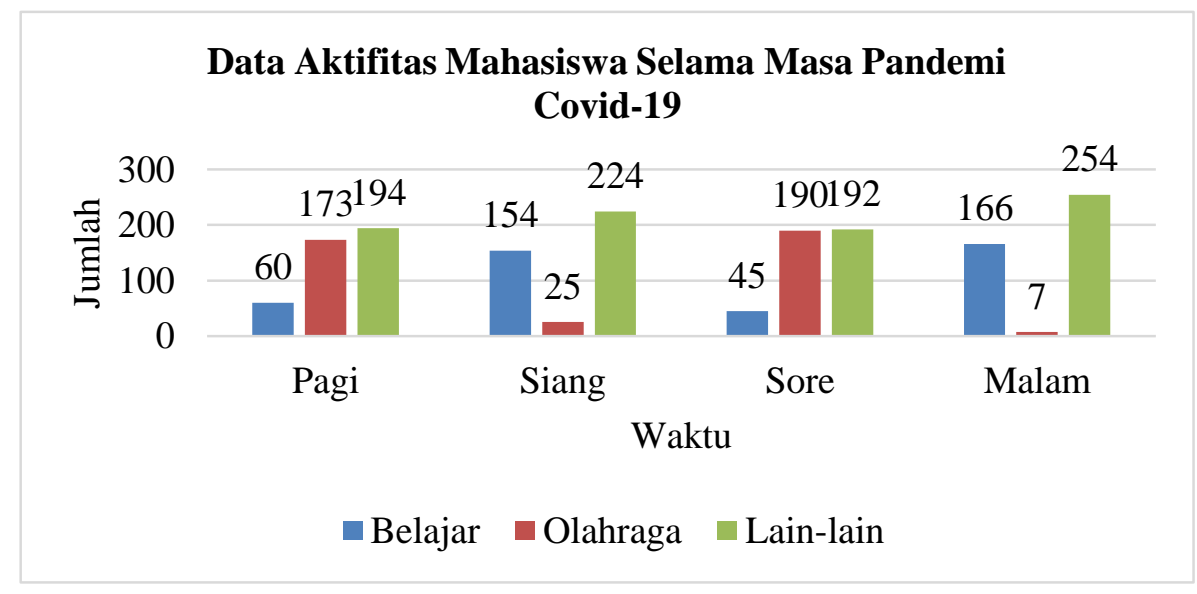

Gambar 3. Data Aktivitas Mahasiswa Selama Masa Pandemi Covid-19 
Dilansir dari berita detiknews 15 Maret 2020, pemerintah membuat kebijakan bagi pelajar dan mahasiswa untuk tidak ke sekolah atau kampus selama masa pandemi covid-19 sehingga kegiatan belajar dilakukan dari rumah. Data penelitian tentang survei aktivitas mahasiswa ketika di rumah dalam masa pandemi covid-19 menunjukan kegiatan belajar pada pagi hari 60 mahasiswa, siang hari 154 mahasiswa, sore hari 45 mahasiswa, dan malam hari 166 mahasiswa. Data kegiatan belajar paling tinggi dilakukan pada malam hari dengan jumlah 166 mahasiswa. Data kegiatan olahraga pada pagi hari dilakukan oleh 173 mahasiswa, siang hari 25 mahasiswa, sore hari 190 mahasiswa, malam hari 7 mahasiswa. Kegiatan olahraga paling banyak dilakukan pada saat sore hari oleh 190 mahasiswa. Data tentang kegiatan lain-lain yang dalakukan mahasiswa ketika di rumah pada pagi hari 194 mahasiswa, siang hari 224 mahasiswa, sore hari 192 mahasiswa, malam hari 254 mahasiswa. Kegiatan lain-lain dapat berupa kegiatan membersihkan rumah, membantu pekerjaan orang tua, tidur, menonton televisi, bermain game, menonton film atau video, dll.

Kinerja tubuh pada saat berolahraga di sore hari menunjukan hasil yang lebih baik dari pada berolahraga di pagi hari, hal tersebut dikarenakan seseorang masih membutuhkan waktu beradaptasi setelah bangun tidur di pagi hari (Heisman, 2013). Penelitian lain menunjukan hasil dari latihan di pagi hari dapat meningkatkan performen yang lebih baik ketika berolahraga di sore hari, latihan yang yang dilakukan pada malam hari dapat meningkatkan ritme amplitudo dari kinerja neuromuscular (Chtourou \& Souissi, 2012). Penelitian dari 70 jenis latihan, waktu, dan adaptasi hormone memang menunjukan perbedaan kinerja fisik pada pagi dan sore hari, sehingga faktor-faktor tersebut perlu diperhatikan oleh para ilmuwan, pelatih, dan atelet dalam melakukan pembinaan olahraga (Seo et al., 2013). Berdasarkan literasi tersebut dapat diartikan bahwa pelaksanaan olahraga dapat dilakukan pagi/siang/sore/malam hari karena memiliki efek yang positif untuk meningkatkan performen maupun kesehatan, yang diperlukan adalah pengaturan pelaksanaan olahraga yang tepat sehingga tubuh mampu beradaptasi dengan baik terhadap pembinaan latihan yang diberikan. 


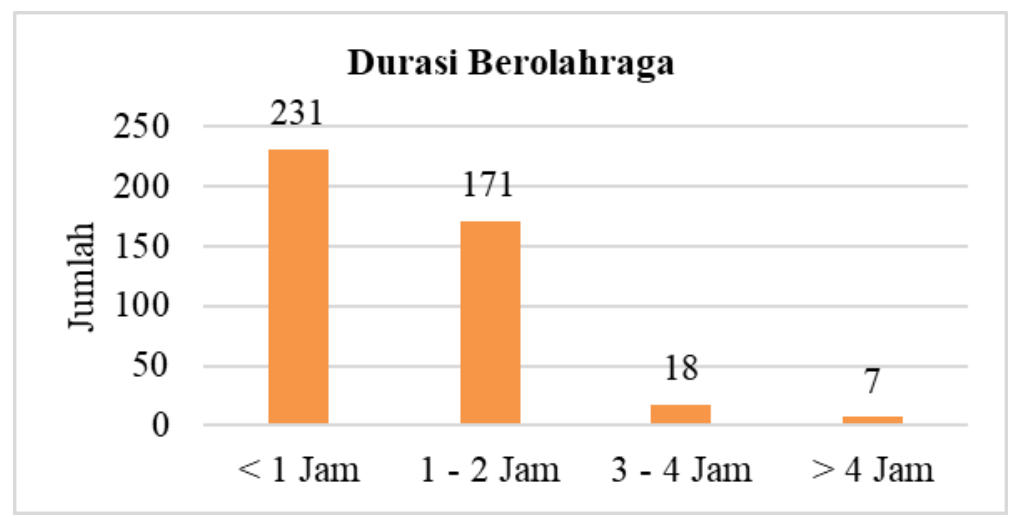

Gambar 4. Durasi Berolahraga

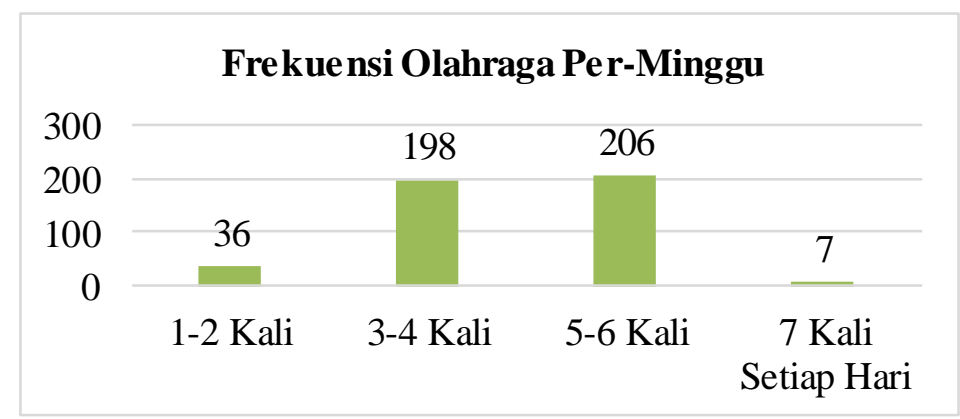

Gambar 5. Frekuensi Olahraga Per-Minggu

Data penelitian menunjukan 231 mahasiswa melakukan latihan dengan durasi < 1 jam, latihan dengan durasi 1-2 jam dilakukan oleh 171 mahasiswa, latihan dengan durasi 3-4 jam dilakukan oleh 18 mahasiswa, latihan dengan durasi $>4$ jam dilakukan oleh 7 mahasiswa. Frekuensi mahasiswa dalam melakukan olahraga per-minggu yaitu: 36 mahasiswa berolahraga 1-2 kali/minggu, 198 mahasiswa berolahraga 3-4 kali/minggu, 206 mahasiswa berolahraga 5-6 kali/minggu, 7 mahasiswa berolahraga 7 kali/minggu.

Menurut WHO bagi orang yang berusia 18-64 tahun direkomendasikan untuk melakukan olahraga aerobik minimal 150 menit per minggu. Latihan dengan durasi 150 menti per minggu dengan intensitas ringan yang didukung dengan gizi yang tepat sesuai kebutuhan juga dianjurkan untuk menurunkan kelebihan berat badan serta meningkatkan kebugaran kardioresporatori (Chambliss, 2005). Pelaksanaan kegiatan olahraga juga perlu memperhatikan teknis secara fisiologis. Olahraga kesehatan dapat dilakukan 10-30 menit tanpa henti dengan frekuensi 3-5 kali per-minggu atau minimal 2 kali per-minggu dengan intensitas setiap latihannya mencapai 60\%-80\% (Wijoyo \& Sidik, 2012). 


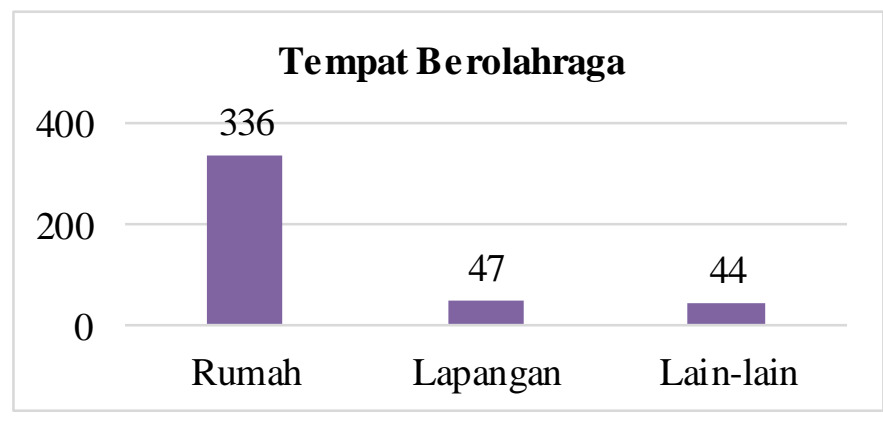

Gambar 6. Tempat Berolahraga

Dari data penelitan menunjukan mahasiswa lebih banyak melakukan aktivitas olahraga di rumah selama pandemi covid-19. Meskipun masih ada 47 mahasiswa yang melakukan olahraga di lapangan dan 44 mahasiswa berolahraga di tempat lain. Olahraga memang dapat dilakukan dimana saja dan kapan saja. Olahraga dapat dilakuakn dengan menggunakan alat maupun tanpa alat. Di media youtube, instagram, blog, siaran televisi, maupun media informasi lainnya banyak menampilkan berbagai aktivitas olahraga yang dapat dilakukan di rumah seperti body work out, senam, latihan beban, latihan kelincahan, kekuatan, dll. Tetap berada di rumah merupakan langkah keamanan yang paling mendasar untuk Tindakan pencegahan, selain itu aktivitas fisik secara teratur dan berolahraga secara rutin di lingkungan rumah merupakan strategi penting untuk hidup sehat selama masa pandemi covid-19 (Chen et al., 2020). Bagi mahasiswa yang merupakan atlet tentunya tetap berlatih di rumah untuk menjaga dan meningkatkan performa tentunya merupakan suatu kewajiban. Perencanaan program latihan yang tepat dengan memperhatikan kondisi atlet serta kebutuhan tentunya dapat membantu meningkatkan kinerja atlet dalam kompetisi (Paramita et al., 2020).

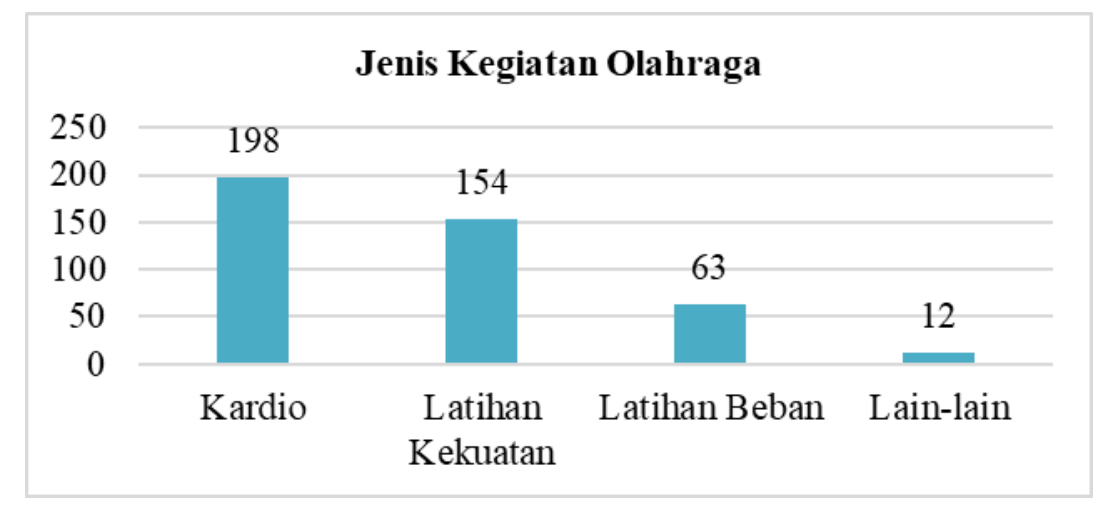

Gambar 7. Jenis Kegiatan Olahraga 
Jumlah mahasiswa yang melakukan jenis olahraga kardio 198 mahasiswa, latihan kekuatan 154 mahasiswa, latihan beban 63 mahasiswa, dan olahraga lainlain 12 mahasiswa. Data penelitian menunjukan latihan kardio yang dilakukan oleh mahasiswa merupakan jenis olahraga yang paling banyak dilakukan ketika masa pandemi covid-19. Latihan atau olahraga kardio termasuk dalam jenis olahraga aerobik. Jenis latihan maupun olahraga yang bersifat aerobik dapat dilakukan dengan durasi sekitar 20-60 menit dengan intensitas latihan 60\%-80\% dari denyut jantung maksimal (Palar et al., 2015).

Kebiasaan berolahraga secara teratur dapat membantu memelihara dan meningkatkan kesehatan dan kebugaran, jenis latihan yang dilakukan dapat berupa yaitu aerobik (jalan, jogging, senam, dll), anaerobik (angkat beban/latihan kekuatan, berlari, medorong, menarik, dll), dan latihan fleksibilitas (stretching, yoga, core stability, dll) (Siddiqui et al., 2010). Latihan kekuatan dapat dilakukan tanpa menggunakan alat, latihannya bisa berupa push up, shit up, back up, plank, body squat, dll. Latihan beban juga dapat dilakukan di rumah dengan memanfaatkan fasilitas sederhana seperti botol bekas air mineral yang diisi air atau pasir, menggunakan dumble, ball medicine, dll. Olahraga teratur dapat meningkatkan kemampuan cardiovascular, mengurangi resiko penyakit jantung, tekanan darah tinggi, penyakit serebrovaskular, kecemasan dan stres (Siddiqui et al., 2010).

Aktivitas fisik dan olahraga akan lebih berdampak positif pada kesehatan apabila didukung dengan asupan gizi yang tepat. Kecukupan gizi tentunya juga berpengaruh terhadap kondisi kesehatan dan kebugaran tubuh (Naja \& Hamadeh, 2020). Berikut merupakan rekomendasi gizi yang optimal untuk menghadapi masa pandemi covid-19. 
Tabel 2. Rekomendasi Gizi serta Strategi Pangan pada Masa Pandemi Covid-19

(Naja \& Hamadeh, 2020).

\begin{tabular}{|c|c|}
\hline $\begin{array}{c}\text { Tingkat } \\
\text { Kebutuhan }\end{array}$ & Rekomendasi Gizi dan Strategi Pangan \\
\hline Individu & $\begin{array}{l}\text { 1. Mengkonsumsi makanan dengan gizi seimbang. } \\
\text { 2. Pilih makanan yang mengandung vitamin A, C, E, B6, B12, } \\
\text { seng, dan zt besi. Seperti: buah jeruk, sayuran berdaun hijau } \\
\text { tua, kacang-kacangan, dan produk susu. } \\
\text { 3. Lakukan pola hidup sehat: olahraga di rumah, tidur teratur, } \\
\text { dan meditasi. } \\
\text { 4. Hindari merokok, alkohol, dan narkoba. } \\
\text { 5. Jangan menyebarkan informasi yang salah terkait dengan } \\
\text { kebutuhan asupan makanan selama masa pandemi covid-19. }\end{array}$ \\
\hline Kominitas & $\begin{array}{l}\text { 1. Memberikan informasi yang tepat serta hindari kepanikan } \\
\text { masal sehingga membeli barang sesuai kebutuhan. } \\
\text { 2. Melakukan identifikasi serta memberikan prioritas gizi } \\
\text { terhadap masyarakat yang beresiko kekurangan gizi, } \\
\text { terutama orang tua dan pasien dengan penyakit kronis. } \\
\text { 3. Membuat sistem yang terstruktur dan terarah untuk } \\
\text { memastikan ketersediaan, akses, dan keterjangkauan } \\
\text { komoditas pangan yang penting bagi semua masyarakat. }\end{array}$ \\
\hline Nasional & $\begin{array}{l}\text { 1. Menentukan, membiayai, dan mendistribusikan paket } \\
\text { makanan untuk kebutuhan masyarakat, memastikan } \\
\text { ketersedian hasil petani lokal serta meminimalkan } \\
\text { ketergantungan pada impor pangan. } \\
\text { 2. Melakukan mobilisasi sumber daya untuk membiayai } \\
\text { pembelian dan penyediaan makanan. } \\
\text { 3. Membebaskan pajak untuk makanan pokok dan komoditas. } \\
\text { 4. Mendukung industri produksi pertanian dan pangan. } \\
\text { 5. Melakukan pemantauan dan memeriksa harga pangan di } \\
\text { pasar. } \\
\text { 6. Membangun jaringan dengan sektor swasta, lembaga } \\
\text { internasional, dan lokal. } \\
\text { 7. Menjaga serta mekukan transparansi dalam membangun } \\
\text { kepercayaan, dukungan, dan pemenuhan kebutuhan. }\end{array}$ \\
\hline Global & $\begin{array}{l}\text { 1. Pada arus perdagangan global perlu menghindari } \\
\text { pembatasan perdagangan untuk menjaga ketersediaan } \\
\text { pangan. } \\
\text { 2. Mengurangi tarif impor dan pembatasan lain pada } \\
\text { komoditas pangan. }\end{array}$ \\
\hline
\end{tabular}

\section{SIMPULAN}

Survei tentang kegiatan olahraga mahasiswa ketika masa pandemi covid-19 menunjukan bahwa meskipun di rumah para mahasiswa tetap rutin melakukan kegiatan olahraga. Kegiatan olahraga yang paling banyak dilakukan adalah jenis 
olahraga kardio yang termasuk dalam kegiatan yang bersifat aerobik. Aktivitas olahraga lebih sering dilakukan pada sore hari. Melakukan olahraga di rumah merupakan salah satu cara untuk meningkatkan kesehatan dan kebugaran serta sebagai tindakan pencegahan untuk agar terhindar dari penyebaran covid-19.

Olahraga memang sangat penting untuk meningkatkan daya tahan tubuh. Olahraga secara teratur serta intensitas yang tepat dapat membantu terhindar dari kematian akibat influenza dan pneumonia. WHO merekomendasikan akitivitas olahraga minimal 150 menit/minggu. Olahraga kesehatan juga dapat dilakukan 35 kali/minggu dengan durasi 10-60 menit dengan intensitas 60\%-80\% dari denyut jantung maksimal. Asupan gizi yang tepat juga sangat mendukung kegiatan olahraga yang dilakukan agar lebih memberi manfaat positif bagi kesehatan dan kebugaran sehingga dapat meningkatkan imunitas tubuh.

\section{DAFTAR RUJUKAN}

Andalasari, R., \& Berbudi BL, A. (2018). Kebiasaan Olah Raga Berpengaruh Terhadap Tingkat Stress Mahasiswa Poltekkes Kemenkes Jakarta III. Jurnal Ilmu Dan Teknologi Kesehatan. 5(2), 179-191. https://doi.org/10.32668/jitek.v5i2.11

Arikunto, S. (2010). Prosedur Penelitian Suatu Pendekatan Praktek. Bandung: Rineka Cipta.

Cegielski, J., Brook, M. S., Quinlan, J. I., Wilkinson, D. J., Smith, K., Atherton, P. J., \& Phillips, B. E. (2017). A 4-week, lifestyle-integrated, home-based exercise training programme elicits improvements in physical function and lean mass in older men and women: a pilot study. F1000Research, 6(0), 1235. https://doi.org/10.12688/f1000research.11894.1

Chambliss, H. O. (2005). Exercise duration and intensity in a weight-loss program. Clinical Journal of Sport Medicine, 15(2), 113-115. https://doi.org/10.1097/01.jsm.0000151867.60437.5d

Chen, P., Mao, L., Nassis, G. P., Harmer, P., Ainsworth, B. E., \& Li, F. (2020). Wuhan coronavirus (2019-nCoV): The need to maintain regular physical activity while taking precautions. Journal of Sport and Health Science, 9(2), 103-104. https://doi.org/10.1016/j.jshs.2020.02.001

Chtourou, H., \& Souissi, N. (2012). The effect of training at a specific time of day: A review. The Journal of Strength \& Conditioning Research, 26(7), 1984-2005. https://doi.org/10.1519/JSC.0b013e31825770a7

Fallon, K. (2020). Exercise in the time of COVID-19. Australian journal of general practice, 49 . https://doi.org/10.31128/ajgp-covid-13 
Garber, C. E., Blissmer, B., Deschenes, M. R., Franklin, B. A., Lamonte, M. J., Lee, I. M., Nieman, D. C., \& Swain, D. P. (2011). Quantity and quality of exercise for developing and maintaining cardiorespiratory, musculoskeletal, and neuromotor fitness in apparently healthy adults: Guidance for prescribing exercise. Medicine and Science in Sports and Exercise. https://doi.org/10.1249/MSS.0b013e318213fefb

He, F., Deng, Y., \& Li, W. (2020). Coronavirus disease 2019: What we know? $\begin{array}{llll}\text { Journal of medical virology, 92(7), 719-725. } & \text {. }\end{array}$ https://doi.org/10.1002/jmv.25766

IOM (Institute of Medicine). (2013). Educating the Student Body: Taking Physical Activity and Physical Education to School. In National Academies Press. https://doi.org/10.17226/18314

Malm, C., Jakobsson, J., \& Isaksson, A. (2019). Physical Activity and SportsReal Health Benefits: A Review with Insight into the Public Health of Sweden. Sports, 7(5), 127. https://doi.org/10.3390/sports7050127

Naja, F., \& Hamadeh, R. (2020). Nutrition amid the COVID-19 pandemic: a multi-level framework for action. European Journal of Clinical Nutrition, 15. https://doi.org/10.1038/s41430-020-0634-3

Olympic. (2020). Tomorrow we're going to celebrate \#OlympicDay the best way we know how - with an Olympic Day workout! Instagram. https://www.instagram.com/p/CBwI1FLJXf-/

Palar, C. M., Wongkar, D., \& Ticoalu, S. H. R. (2015). Manfaat Latihan Olahraga Aerobik Terhadap Kebugaran Fisik Manusia. eBiomedik, 3(1). https://doi.org/10.35790/ebm.3.1.2015.7127

Paramita, D. A., Sinrang, A. W., \& Santoso, A. (2020). Correlation Between Exercise Program With Lung Function And Achievements In Young Adult Swimmer. Jurnal Pendidikan Jasmani, Olahraga Dan Kesehatan, 3(2), 201-212.

Prasetyo, Y. (2013). Kesadaran Masyarakat Berolahraga untuk Peningkatan Kesehatan dan Pembangunan Nasional. Medikora, 11(2)

Riyanto, Y. (2010). Metodologi Penelitian Pendidikan. Surabaya : SIC.

Ruegsegger, G. N., \& Booth, F. W. (2018). Health benefits of exercise. Cold Spring Harbor Perspectives in Medicine. https://doi.org/10.1101/cshperspect.a029694

Seo, D. Y., Lee, S., Kim, N., Ko, K. S., Rhee, B. D., Park, B. J., \& Han, J. (2013). Morning and evening exercise. Integrative Medicine Research. https://doi.org/10.1016/j.imr.2013.10.003

Siddiqui, N. I., Nessa, A., \& Hossain, M. A. (2010). Regular physical exercise: way to healthy life. In Mymensingh medical journal : MMJ. 
Sugiyono. (2010). Metode Penelitian Pendidikain. Bandung : Alfabeta.

Warburton, D. E. R., \& Bredin, S. S. D. (2017). Health benefits of physical activity: A systematic review of current systematic reviews. In Current Opinion in Cardiology. https://doi.org/10.1097/HCO.0000000000000437

Wijoyo, S. G., \& Sidik, D. Z. (2012). Ilmu Kesehatan Olahraga. Bandung : PT. Remaja Rosdakarya. 